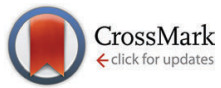

Cite this: J. Mater. Chem. B, 2016, 4, 1499

Received 7th December 2015, Accepted 28th January 2016

DOI: $10.1039 / c 5 t b 02569 a$

www.rsc.org/MaterialsB

\section{Synthesis, characterization and biological evaluation of a new photoactive hydrogel against Gram-positive and Gram-negative bacteria $\dagger$}

\author{
Cinzia Spagnul, ${ }^{a}$ John Greenman, ${ }^{\mathrm{b}}$ Mark Wainwright, ${ }^{\mathrm{C}}$ Zeeniya Kamil $^{\mathrm{b}}$ and \\ Ross W. Boyle*a
}

\begin{abstract}
In 2013, the World Health Organization reported that 884 million people lack access to clean potable water. Photodynamic antimicrobial chemotherapy (PACT) is a very promising alternative to conventional antibiotics for the efficient inactivation of pathogenic microorganisms. We report the synthesis, characterization and antibacterial activity of a polyacrylamide-based hydrogel (7), with a new photoactive phenothiazinium compound (6) immobilized on it, to be used as a novel water-sterilizing device. The hydrogel was characterized by $I R$ and scanning electron microscopy and incorporation of the dye confirmed by UV-visible spectroscopy. Antibacterial tests using the recombinant bioluminescent Gram-positive Staphylococcus aureus RN4220 and Gram-negative Escherichia coli DH5 $\alpha$ were performed to assess the ability of the hydrogel to inactivate bacterial strains in solution. The hydrogel is characterized by a non-ordered microporous structure and is able to generate reactive oxygen species. The hydrogel is able to inactivate planktonic cells of the $S$. aureus and E. coli ( $3.3 \mathrm{log}$ and $2.3 \mathrm{log}$ killing, respectively) after $25 \mathrm{~min}$ of irradiation with white light at $14.5 \mathrm{~mW} \mathrm{~cm}^{-2}$. The contact surface does not influence the kill rates while the killing rate increased by increasing the total amount of the hydrogel $(0.27 \log$ drop to $1.65 \mathrm{log}$ drop with $0.5 \mathrm{mg} \mathrm{cm}^{-3}$ to $2.5 \mathrm{mg} \mathrm{cm}^{-3}$ of total amount of dye). The hydrogel was found to be active for four cycles, suggesting the possibility of reuse and it was shown to be active against both Gram-positive and Gram-negative species with no leaching of the active molecule.
\end{abstract}

\section{Introduction}

Ensuring access to clean and reliable water is a major, worldwide, challenge. In 2013, the World Health Organization reported that 884 million people lack access to clean potable water. ${ }^{1}$ In the developed countries, the number of people without an improved water source in urban areas increases with population growth ${ }^{2}$ while in developing countries one million eight hundred thousand people die every year from diarrheal diseases, $88 \%$ of which are attributed to unsafe water supply and inadequate hand washing and hygiene. ${ }^{3,4}$ Therefore, the removal of harmful microorganisms, such as bacteria, viruses and protozoa, assumes great significance. The increasing prevalence of bacterial resistance to antibiotics

\footnotetext{
${ }^{a}$ Department of Chemistry, University of Hull, Kingston-upon-Hull, East Yorkshire, HU6 7RX, UK. E-mail: r.w.boyle@hull.ac.uk; Fax: +44 (o)1482 466410; Tel: +44 (0)1482 466353

${ }^{b}$ School of Life Sciences, University of the West of England, Bristol, BS16 1QY, UK ${ }^{c}$ School of Pharmacy and Biomolecular Sciences, Liverpool John Moores University, Liverpool, L3 2AJ, UK

$\dagger$ Electronic supplementary information (ESI) available: Fig. S1-S11. See DOI: $10.1039 / \mathrm{c} 5$ tb02569a
}

is also a clinical threat worldwide for which an urgent solution is needed. ${ }^{5}$

Photodynamic antimicrobial chemotherapy (PACT) has emerged as an attractive strategy for microbial inactivation. ${ }^{6-8}$ PACT is based on the concept that a non-toxic chemical molecule (named photosensitiser, PS), can be activated by visible light of appropriate wavelength to generate highly toxic, but short-lived, reactive oxygen species (ROS), which include singlet oxygen, superoxide radical, hydroxyl radicals and hydrogen peroxide. Unlike antibiotics, which usually have a single-target mechanism leading to biocidal action, ROS act via a multi-targeted mechanism, thereby reducing and delaying the probability of emergence of new resistance mechanisms and helping in retaining the activity of conventional antibiotics by limiting their, often inappropriate, use. $^{9,10}$

Although Gram-positive and Gram-negative bacteria are both susceptible to the photosensitising action of both cationic and anionic sensitisers under certain conditions, Gram-negative bacteria are less prone to be killed due to the complex architecture of their bacterial cell membrane, that acts as an effective barrier to the penetration into the cell of many photosensitising dyes. ${ }^{11}$ Only cationic dyes allow an extensive photo-induced inactivation of both 
types. The selection of an appropriate photosensitiser is therefore a critical step in PACT.

Different photosensitisers, both cationic and anionic, have been widely tested, against Gram-positive and Gram-negative bacteria both in solution $^{12}$ or immobilized onto a surface. ${ }^{13}$

Cationic phenothiazines, such as methylene blue (MB) and toluidine blue (TBO) have a well-documented killing ability towards viruses and, bacteria in blood fractions ${ }^{14-16}$ and for plasma sterilization. They are active both in solution and incorporated into polymeric materials, such as silicone, ${ }^{17-20}$ polysiloxane polymers, ${ }^{21}$ polyurethane, ${ }^{22,23}$ polyethylene, ${ }^{24}$ and cellulose acetate. ${ }^{25-27}$

These antimicrobial polymers showed significant antimicrobial activity against Staphylococcus aureus (MRSA), ${ }^{20,23,25,26}$ Escherichia coli, ${ }^{18,19,23,24,26}$ Staphylococcus epidermidis, ${ }^{17-19}$ Staphylococcus aureus, ${ }^{22,24,26,27}$ and Pseudomonas aeruginosa. ${ }^{25}$

Immobilization onto an inert support offers many advantages. An effective attachment of the photosensitiser allows for its complete removal from the treated water, thus eliminating any photosensitiser contamination of the water, which would not be acceptable for water disinfection.

Secondly, immobilization may enable the re-use of the active gel over several cycles of use, thus increasing its renewability and friendliness towards the environment. Other possible benefits include the re-use of the photosensitiser, which consequently reduces the cost of the treatment, and the gradual photobleaching of the dyes by solar light, which prevents their accumulation in the environment.

Herein we describe the first prototype of a polyacrylamide hydrogel with a new cationic phenothiazinium dye covalently immobilized into the gel matrix (Fig. 1). The gel was then deposited onto plastic petri dishes to create inexpensive devices for photosterilization.

As inert support we choose a polyacrylamide hydrogel because it is among the most commonly applied and well-studied gel material systems due to their utility for high-resolution electrophoretic separation of proteins and DNA. ${ }^{28}$ It's a porous structure, transparent, cheap, versatile and highly compatible with biological systems.

Furthermore in this study we used a rapid method ${ }^{29}$ to assess the antibacterial effect of the hydrogel system by the real-time reduction in the light output of recombinant bioluminescent E. coli DH5 $\alpha$ and the Gram-positive S. aureus RN4220 (MRSA)

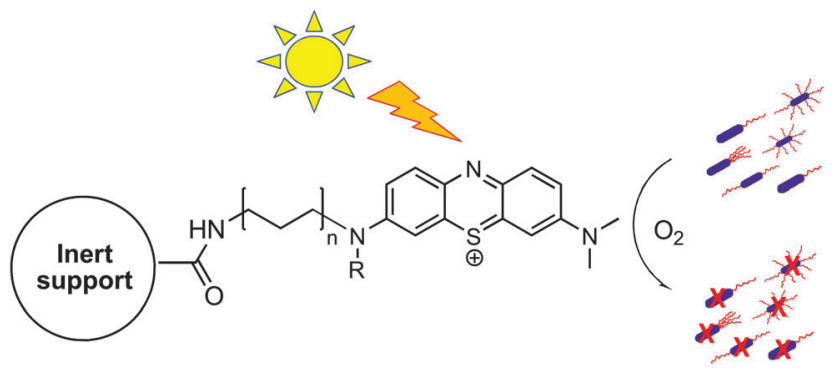

Fig. 1 Schematic drawing of the photodynamic inactivation of microorganisms by singlet oxygen generated by the photosensitiser immobilized on an inert support. under artificial irradiation. Since E. coli is an indicator of fecal pollution and is used to evaluate the quality of drinking, recreational and residual waters, it can be considered to be an appropriate target species for modeling the likely final conditions of practical use of the device.

\section{Experimental}

Mono and bidimensional ( $\mathrm{H}-\mathrm{H}$ COSY), ${ }^{1} \mathrm{H}$ NMR spectra were recorded at ambient temperature on a JEOL Eclipse 400 and JEOL Lambda 400 spectrometers (operating at $400 \mathrm{MHz}$ for ${ }^{1} \mathrm{H}$ and $100 \mathrm{MHz}$ for ${ }^{13} \mathrm{C}$ ). In all the solvents chemical shifts were referenced to the peak of residual non deuterated solvent $\left(\delta=7.26\right.$ for $\mathrm{CDCl}_{3}, 4.89$ for $\mathrm{D}_{2} \mathrm{O}, 2.50$ for DMSO- $\left.d_{6}\right)$. Coupling constants ( $J$ values) are reported in Hertz $(\mathrm{Hz})$ and are $\mathrm{H}-\mathrm{H}$ coupling constants unless otherwise stated. Assignments were performed through conventional $2 \mathrm{D}$ correlation spectra.

UV-visible spectra were obtained at $T=25{ }^{\circ} \mathrm{C}$ on a Varian Cary 50 Bio UV-vis spectrophotometer using $1.0 \mathrm{~cm}$ path-length quartz cuvettes $(3.0 \mathrm{~mL})$. UV-visible spectra of the solid samples were obtained on the same spectrophotometer used for samples in solution, by placing the gel vertically in the beam of the instrument.

Infrared spectra were obtained on a Nicolet IS5 Spectrometer operating in ATR mode with frequencies given in reciprocal centimeters $\left(\mathrm{cm}^{-1}\right)$. Mass spectra of compound 6 and its precursors were obtained from the EPSRC National Mass Spectrometry Service, Swansea.

All reactions were monitored by thin-layer chromatography (TLC) on precoated SIL G/UV254 silica gel plates $(254 \mu \mathrm{m})$. Column chromatography was performed on silica gel $60 \mathrm{~A}$ (40-63 micron), eluting with dichloromethane/ethanol mixtures as specified below. Commercial solvents and reagents were used without further purification unless stated otherwise.

Chemical reagents were purchased from Sigma-Aldrich, Fluka, Acros, Alfa Aesar at the highest grade of purity available, and were used as received, unless otherwise stated.

All other solvents were purchased from Fisher Scientific and used as received. $\mathrm{N}$-Boc-2,2'-(ethylenedioxy)-diethylamine was prepared according to a published procedure. ${ }^{30}$

The elemental analysis of the compounds 4, 5, 6 was not performed due to the variable content of solvent after column purification or to the variable amounts of crystallization solvent that depend on the batch.

For this reason, elemental analysis of such conjugates did not afford reliable and reproducible results and the values are not reported here (typically, some of the elemental analysis values, especially for $\mathrm{C}$, differ from calculated values by $>0.5 \%$ ). Nevertheless, the purity calculated from elemental analysis data was always $>95 \%$, and the proposed formulas are all consistent with the ${ }^{1} \mathrm{H}$ NMR and ESI MS spectra. RP-HPLC analyses were performed on a system consisting of a Perkin Elmer series 220 LC pump (LC Pump, Series 220) coupled to a UV-vis detector (785A; Perkin-Elmer) with detection at $600 \mathrm{~nm}$.

Analytical separations were performed on Phenomenex ${ }^{\circledR}$ SB-C18 column $150 \mathrm{~mm} \times 4.6 \mathrm{~mm}$ packed with $5 \mu \mathrm{m}$ particle size. 
The mobile phase consisted of two solutions namely A and B. Solution A was made from $0.1 \mathrm{M}$ ammonium acetate and acetic acid ( $\mathrm{pH}$ 5.3), whereas solution B was acetonitrile. The gradient elution was $5 \% \mathrm{~A}$ and $95 \% \mathrm{~B}$ in $15 \mathrm{~min}$ with a flow rate of

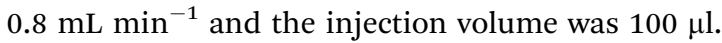

\section{Synthesis and characterization of compounds}

Phenothiazin-5-ium tetraiodide hydrate (1). A procedure similar to that described in the literature was used ${ }^{31}$ with the following parameters: a solution of iodine $(8.0 \mathrm{~g}, 31.52 \mathrm{mmol}$, 3 equiv.) in chloroform ( $200 \mathrm{~mL}$ ) was added to a stirred solution of phenothiazine (2.0 g, $10.03 \mathrm{mmol}, 1$ equiv.) in chloroform $(45 \mathrm{~mL})$ within $1 \mathrm{~h}$ at room temperature. The reaction mixture was then stirred for a further $5 \mathrm{~h}$ and it was monitored by thinlayer chromatography on silica gel $\left(\mathrm{CH}_{2} \mathrm{Cl}_{2} / \mathrm{MeOH} 90\right.$ : 10). The resultant precipitate was filtered, washed with chloroform $(2 \times 50 \mathrm{~mL})$, diethyl ether $(2 \times 50 \mathrm{~mL})$ and then dried under vacuum at room temperature to give the phenothiazine tetraiodide $(6.79 \mathrm{~g}, 93 \%)$ as a black solid.

Found C, 20.42; H, 1.14; N, 1.98; S, 4.54. Calcd for $\mathrm{C}_{12} \mathrm{H}_{8} \mathrm{I}_{4} \mathrm{NS}: \mathrm{C}, 19.91 ; \mathrm{H} 1.39 ; \mathrm{N} 1.93 ; 4.43 \%$.

$\lambda_{\text {max }}\left(\mathrm{DMSO}, 25{ }^{\circ} \mathrm{C}\right) / \mathrm{nm} 643\left(\varepsilon / \mathrm{dm}^{3} \mathrm{~mol}^{-1} \mathrm{~cm}^{-1} 5690\right)$.

IR (neat): $\nu\left(\mathrm{cm}^{-1}\right)=1558,1142,1380,1314,1240,1153$, 1132, 1072, 1027, 744.

${ }^{1} \mathrm{H}\left(400 \mathrm{MHz}\right.$; DMSO- $\left.d_{6}\right) \delta: 7.61(1 \mathrm{H}, \mathrm{t}, J=7.5 \mathrm{~Hz}), 7.72(1 \mathrm{H}$, $\mathrm{t}, J=7.5 \mathrm{~Hz}), 7.91(1 \mathrm{H}, \mathrm{d}, J=7.8 \mathrm{~Hz}), 8.06(1 \mathrm{H}, \mathrm{d}, J=7.8 \mathrm{~Hz}), 8.10$ $(2 \mathrm{H}, \mathrm{m}), 8.48(2 \mathrm{H}, \mathrm{m})$.

${ }^{13} \mathrm{C}\left(100 \mathrm{MHz}\right.$ DMSO- $\left.d_{6}\right) \delta: 152.8,130.2,129.8,129.1,127.4$.

ESI-MS $(\mathrm{m} / \mathrm{z})\left(\mathrm{MeOH}+\mathrm{NH}_{4} \mathrm{OAc}\right): 198.04$ found $\left(\mathrm{M}+\mathrm{H}^{+}\right)$: 199.04.

3-(Dimethylamino)phenothiazin-5-ium Triiodide (2). To a solution of phenothiazin-5-ium tetraiodide hydrate $(1.00 \mathrm{~g}$, $1.38 \mathrm{mmol}, 1$ equiv.) dissolved in dichloromethane $(30 \mathrm{~mL})$, methanol $(1 \mathrm{~mL})$ and acetone $(1 \mathrm{~mL})$ was added solution of dimethylamine (40 wt\% in $\mathrm{H}_{2} \mathrm{O}$ ) in methanol $(2 \mathrm{M}, 1.03 \mathrm{~mL}$, $2.07 \mathrm{mmol}, 1.5$ equiv.) dropwise over $6 \mathrm{~h}$ under Argon. The formation of the product was monitored by thin-layer chromatography on silica gel $\left(\mathrm{CH}_{2} \mathrm{Cl}_{2} / \mathrm{CH}_{3} \mathrm{OH} 90: 10\right)$.

The reaction mixture was diluted with dichloromethane $(100 \mathrm{~mL})$ and washed with water. The organic layer was dried over anhydrous $\mathrm{Na}_{2} \mathrm{SO}_{4}$, filtered and concentrated under reduced pressure. The product was washed with diethyl ether to give the compound as dark-blue solid (0.30 g, 35\%).

Found $\mathrm{C}, 27.23 ; \mathrm{H}, 1.86 ; \mathrm{N}, 4.50 ; \mathrm{S}, 5.25 \%$. Calcd for $\mathrm{C}_{14} \mathrm{H}_{13} \mathrm{I}_{3} \mathrm{~N}_{2} \mathrm{~S}$ : C, 27.03; H, 2.11; N, 4.50; S, 5.15\%.

$\lambda_{\text {max }}\left(\mathrm{DMSO}, 25{ }^{\circ} \mathrm{C}\right) / \mathrm{nm} 580\left(\varepsilon / \mathrm{dm}^{3} \mathrm{~mol}^{-1} \mathrm{~cm}^{-1} 7424\right), 415$ (6473) and 301 (13766).

IR (neat): $\nu\left(\mathrm{cm}^{-1}\right)=2923,2849,1616,1589,1560,1496,1461$, 1428, 1311, 1251, 1118, 1075, 881, 831, 769, 742.

${ }^{1} \mathrm{H}\left(400 \mathrm{MHz}\right.$, DMSO- $\left.d_{6}\right) \delta: 8.23(\mathrm{dd}, J=7.9 \mathrm{~Hz}, J=1.5 \mathrm{~Hz}$, $1 \mathrm{H}, \mathrm{H}-9$ ), 8.18 (dd, $J=8.0 \mathrm{~Hz}, J=1.5 \mathrm{~Hz}, 1 \mathrm{H}, \mathrm{H}-6), 8.10$ (d, $J=10.0 \mathrm{~Hz}, 1 \mathrm{H}, \mathrm{H}-1), 8.06$ (d, $J=2.6 \mathrm{~Hz}, 1 \mathrm{H}, \mathrm{H}-2$ ), 8.02 (dd, $J=7.7 \mathrm{~Hz}, J=2.6 \mathrm{~Hz}, 1 \mathrm{H}, \mathrm{H}-4), 7.81-7.91(2 \mathrm{H}, \mathrm{m}, J=9.6 \mathrm{~Hz}$, $7.6 \mathrm{~Hz}, 1.6 \mathrm{~Hz}, \mathrm{H}-7, \mathrm{H}-8), 3.66$ (s, 3H, $\mathrm{NCH}_{3}$ ), 3.60 (s, 3H, $\mathrm{NCH}_{3}$ ).

${ }^{13} \mathrm{C}\left(100 \mathrm{MHz}, \mathrm{DMSO}-d_{6}\right) \delta: 140.4,137.9,135.1,133.8,130.4$, 130.0, 129.0, 128.5, 128.0, 126.9, 126.7, 110.3, 43.9, 43.4.
ESI-MS $(m / z)\left(\mathrm{MeOH}+\mathrm{NH}_{4} \mathrm{OAc}\right)$ : calcd for $\mathrm{C}_{14} \mathrm{H}_{13} \mathrm{~N}_{2} \mathrm{~S}$ : 241.0794 found $\left(\mathrm{M}^{+}\right): 241.0793$.

$\mathrm{N}$-\{2-[2-(2-tert-Butoxycarbonylaminoethoxy)ethoxy]ethyl\}acrylamide (4). $\mathrm{N}$-Boc-2,2'-(ethylenedioxy)-diethylamine (3) $(1.0 \mathrm{~g}$, $4.03 \mathrm{mmol}, 1$ equiv.) and diisopropylethylamine $(1.40 \mathrm{~mL}$, $8.05 \mathrm{mmol}, 2$ equiv.) were dissolved in dry dichloromethane $(10 \mathrm{~mL})$ in an argon atmosphere. Acryloyl chloride $(327 \mu \mathrm{l}$, 8.05 mmol, 2 equiv.) was added dropwise over 3 hours at $0{ }^{\circ} \mathrm{C}$. The reaction mixture was stirred for $4 \mathrm{~h}$, while being allowed to reach room temperature, then it was diluted with dichloromethane, and washed with $5 \%$ aqueous solution of citric acid and brine. The organic fraction was concentrated, dried with $\mathrm{MgSO}_{4}$, concentrated under reduced pressure and the crude product was purified by column chromatography $\left(\mathrm{CH}_{2} \mathrm{Cl}_{2} / \mathrm{MeOH}\right.$ 95:5) to give $0.85 \mathrm{~g}$ of 4 as a pure pale yellow oil in $70 \%$ yield.

${ }^{1} \mathrm{H}\left(400 \mathrm{MHz}, \mathrm{CDCl}_{3}\right) \delta: 6.29\left(\mathrm{dd}, J_{\text {trans }}=17.0 \mathrm{~Hz}, J_{\text {gem }}=\right.$ $\left.1.6 \mathrm{~Hz}, 1 \mathrm{H}, \mathrm{CH}_{2} \mathrm{CHCO}\right), 6.12\left(\mathrm{dd}, J_{\text {trans }}=17.0 \mathrm{~Hz}, J_{\text {cis }}=10.2 \mathrm{~Hz}\right.$, $1 \mathrm{H}, \mathrm{CH}_{2} \mathrm{CHCO}$ ), $5.63\left(\mathrm{dd}, J_{\text {cis }}=10.2 \mathrm{~Hz}, J_{\text {gem }}=1.6 \mathrm{~Hz}, 1 \mathrm{H}\right.$, $\mathrm{CH}_{2} \mathrm{CHCO}$ ), 5.00 (brs, 1H, NHCO), 3.71-3.39 (m, 10H, $\mathrm{CH}_{2 \mathrm{peg}}$ ), 3.31 (m, 2H, $\mathrm{CH}_{2} \mathrm{NHCOBoc}$ ), 1.43 (s, 9H, $\mathrm{CH}_{3} \mathrm{Boc}$ ).

${ }^{13} \mathrm{C}\left(100 \mathrm{MHz}_{\mathrm{CDCl}}\right) \delta: 167.48,157.34,130.9,126.5,80.6$, 70.4, 70.3, 70.2, 69.8, 40.4, 39.4, 28.5.

ESI-MS $(\mathrm{m} / \mathrm{z})$ : calcd for $\mathrm{C}_{14} \mathrm{H}_{26} \mathrm{~N}_{2} \mathrm{O}_{5}: 302.18$; found: $(\mathrm{M}+$ $\mathrm{Na})^{+}: 325.17$.

$\mathrm{N}$-\{2-[2-(2-aminoethoxy)ethoxy]ethyl\}acrylamide (5). $\mathrm{N}-\{2-[2-$ (2-tert-Butoxycarbonylaminoethoxy)ethoxy]ethyl acrylamide (2) (1.27 g, $4.20 \mathrm{mmol}, 1$ equiv.) was treated with $4 \mathrm{M} \mathrm{HCl}$ in 1,4-dioxane (2.52 mL, $10.08 \mathrm{mmol}, 2.4$ equiv.). The resulting solution was stirred at room temperature for $1 \mathrm{~h}$, and the solvent was evaporated. The residue was triturated with diethyl ether and thoroughly dried in vacuo to afford $0.82 \mathrm{~g}$ of 5 as a yellow oil in $92 \%$ yield.

${ }^{1} \mathrm{H}\left(400 \mathrm{MHz}, \mathrm{D}_{2} \mathrm{O}\right) \delta: 6.26\left(\mathrm{dd}, J_{\text {trans }}=17.1 \mathrm{~Hz}, J_{\text {cis }}=10.0 \mathrm{~Hz}\right.$, $1 \mathrm{H}, \mathrm{CH}_{2} \mathrm{CHCO}$ ), $6.17\left(\mathrm{dd}, J_{\text {trans }}=17.1 \mathrm{~Hz}, J_{\text {gem }}=1.6 \mathrm{~Hz}, 1 \mathrm{H}\right.$, $\mathrm{CH}_{2} \mathrm{CHCO}$ ), 5.75 (dd, $J_{\text {cis }}=10.0 \mathrm{~Hz}, J_{\text {gem }}=1.6 \mathrm{~Hz}, 1 \mathrm{H}$, $\mathrm{CH}_{2} \mathrm{CHCO}$ ), 3.80-3.57 (m, 10H, $\mathrm{CH}_{2 \text { peg }}$ ), 3.47 (t, $2 \mathrm{H}, J=5.4 \mathrm{~Hz}$, $\left.\mathrm{CH}_{2} \mathrm{NHCOCH}\right), 3.19\left(\mathrm{~m}, 2 \mathrm{H}, \mathrm{CH}_{2} \mathrm{NH}_{2}\right)$.

${ }^{13} \mathrm{C}\left(400 \mathrm{MHz}, \mathrm{D}_{2} \mathrm{O}\right) \delta: 129.9,127.5,69.6,68.8,66.4$, $39.1,38.9$.

ESI-MS $(m / z)\left(\mathrm{MeOH}+\mathrm{NH}_{4} \mathrm{OAc}\right)$ : calcd for $\mathrm{C}_{9} \mathrm{H}_{19} \mathrm{~N}_{2} \mathrm{O}_{3}$ : 202.1387; found $\left(\mathrm{M}+\mathrm{H}^{+}\right)$: 203.1387.

3-(2-(2-(2-Acrylamidoethoxy)ethoxy)ethylamino)-7-(dimethylamino)phenothiazin-5-ium chloride (6). A procedure from the literature $^{32}$ was modified as follows: to a solution of 3-dialkylaminophenothiazinium triiodide ( $100 \mathrm{mg}, 0.16 \mathrm{mmol}, 1$ equiv.) in anhydrous methanol $(20 \mathrm{~mL})$ was added dropwise under argon the alkyl amine 5 ( $49 \mathrm{mg}, 0.24 \mathrm{mmol}, 1.5$ equiv.) previously dissolved in $12.5 \mathrm{~mL}$ of anhydrous methanol. The reaction was allowed to stir at room temperature for 2 hours and the formation of the product was monitored by thin-layer chromatography on silica gel $\left(\mathrm{CH}_{2} \mathrm{Cl}_{2} / \mathrm{CH}_{3} \mathrm{OH} 90: 10\right)$.

The product was isolated by evaporation of the methanol, redissolution in dichloromethane $(50 \mathrm{~mL})$ and extraction with water $(2 \times 100 \mathrm{~mL})$.

The water extracts were concentrated under reduced pressure (5 $\mathrm{mL}$ ) and passed though a small column (height $5 \mathrm{~cm}$, 
diameter $2 \mathrm{~cm}$ ) packed with ion exchange resin (Amberlite IRA400) previously rinsed with acidic sodium chloride solution ( $10 \%$ aqueous $\mathrm{NaCl}$ cont. $0.1 \% \mathrm{HCl}, 100 \mathrm{~mL}$ ) and conditioned with dilute hydrochloric acid (0.1\%) eluting with double distilled water $(40 \mathrm{~mL})$. The aqueous solution was evaporated under vacuum to give the product as dark blue solid. Compounds still impure by thin-layer chromatography at this stage were chromatographed on silica gel using gradient elution in dichloromethane/ ethanol 99:5. The product was obtained as a dark blue solid $(0.39 \mathrm{~g}, 76 \%)$.

$\lambda_{\max }\left(\right.$ water, $\left.25{ }^{\circ} \mathrm{C}\right) / \mathrm{nm} 627\left(\varepsilon / \mathrm{dm}^{3} \mathrm{~mol}^{-1} \mathrm{~cm}^{-1} 7463\right), 584$ (9953) and 421 (8211).

IR (neat): $\nu\left(\mathrm{cm}^{-1}\right)=2923,2349,1657,1624,1551,1496$, 1435, 1314, 1250, 1121, 1095, 747, 724.

${ }^{1} \mathrm{H}\left(400 \mathrm{MHz}, \mathrm{DMSO}-d_{6}\right)$ (as the iodide salt) $\delta: 8.24(\mathrm{t}, J=5.0$ $\mathrm{Hz}, 1 \mathrm{H}, \mathrm{CH}_{2} \mathrm{NHAr}$ ), 8.14-7.78 (m, 6H, H aromatic), 6.26 (dd, $\left.J_{\text {trans }}=17.1, J_{\text {cis }}=10.1 \mathrm{~Hz}, 1 \mathrm{H}, \mathrm{CH}_{2} \mathrm{CHCO}\right), 6.08\left(\mathrm{dd}, J_{\text {trans }}=17.1\right.$ $\left.\mathrm{Hz}, J_{\text {gem }}=3.3 \mathrm{~Hz}, 1 \mathrm{H}, \mathrm{CH}_{2} \mathrm{CHCO}\right), 5.58\left(\mathrm{dd}, J_{\text {cis }}=10.1 \mathrm{~Hz}\right.$, $\left.J_{\text {gem }}=3.3 \mathrm{~Hz}, 1 \mathrm{H}, \mathrm{CH}_{2} \mathrm{CHCO}\right), 3.70-3.54\left(\mathrm{~m}, 10 \mathrm{H}, \mathrm{CH}_{2 \text { peg }}+\right.$ $\left.\mathrm{N}\left(\mathrm{CH}_{3}\right)_{2}\right), 3.47-3.44(\mathrm{t}, 1 \mathrm{H}, \mathrm{CONH}), 3.29\left(\mathrm{~m}, 2 \mathrm{H}, \mathrm{CH}_{2} \mathrm{CONH}\right)$, 3.03-2.86 (m, 2H, $\left.\mathrm{CH}_{2} \mathrm{NH}_{2}\right)$.

${ }^{1} \mathrm{H}\left(400 \mathrm{MHz}\right.$, DMSO- $d_{6}$ ) (as chloride salt) $\delta: 8.33(\mathrm{t}, J=$ $5.0 \mathrm{~Hz}, 1 \mathrm{H}, \mathrm{CH}_{2} \mathrm{NHAr}$ ), 8.27-8.01 (m, $6 \mathrm{H}, \mathrm{H}$ aromatic), 6.28 (dd, $\left.J_{\text {trans }}=17.1, J_{\text {cis }}=10.1 \mathrm{~Hz}, 1 \mathrm{H}, \mathrm{CH}_{2} \mathrm{CHCO}\right), 6.07\left(\mathrm{dd}, J_{\text {trans }}=\right.$ $\left.17.1 \mathrm{~Hz}, J_{\text {gem }}=3.3 \mathrm{~Hz}, 1 \mathrm{H}, \mathrm{CH}_{2} \mathrm{CHCO}\right), 5.57\left(\mathrm{dd}, J_{\text {cis }}=10.1 \mathrm{~Hz}\right.$, $\left.J_{\text {gem }}=3.3 \mathrm{~Hz}, 1 \mathrm{H}, \mathrm{CH}_{2} \mathrm{CHCO}\right), 3.72-3.57\left(\mathrm{~m}, 16 \mathrm{H}, \mathrm{CH}_{2 \mathrm{peg}}+\right.$ $\left.\mathrm{N}\left(\mathrm{CH}_{3}\right)_{2}\right), 3.47-3.44(\mathrm{t}, 1 \mathrm{H}, \mathrm{CONH}) 3.29\left(\mathrm{~m}, 2 \mathrm{H}, \mathrm{CH}_{2} \mathrm{CONH}\right)$, 3.03-2.86 (m, $\left.2 \mathrm{H}, \mathrm{CH}_{2} \mathrm{NH}\right)$.

${ }^{13} \mathrm{C}\left(100 \mathrm{MHz}, \mathrm{DMSO}-d_{6}\right) \delta: 140.4,139.8,135.1,133.4,132.4$, 130.4, 128.4, 127.9, 126.9, 126.9, 125.6, 110.3, 70.2, 70.0, 69.5, $67.1,40.5,40.7,39.1,38.9$.

ESI-MS $(m / z)\left(\mathrm{MeOH}+\mathrm{NH}_{4} \mathrm{OAc}\right): 439.1796$ found $\left(\mathbf{M}^{+}\right)$ 439.1798 .

HPLC: $t_{\mathrm{R}}: 5.92 \mathrm{~min}$.

Synthesis of the photoantimicrobial hydrogel (7). $1.91 \mathrm{~g}$ of acrylamide (26.87 mmol), $66 \mathrm{mg}$ of $N, N^{\prime}$-methylenebisacrylamide $(0.43 \mathrm{mmol})$ were dissolved in $6.6 \mathrm{~mL}$ of water. $100 \mu \mathrm{l}$ of a $10 \%$ solution of sodium dodecylsulphate (SDS) $(9.95 \mathrm{mg}$, $0.035 \mathrm{mmol}, 1.5$ equiv.) and 6 (11 $\mathrm{mg}, 0.023 \mathrm{mmol}, 1$ equiv.) previously dissolved in $3.3 \mathrm{~mL}$ of double distilled water were subsequently added the solution was gently stirred. $100 \mu \mathrm{l}$ of a $10 \%$ solution of APS and $20 \mu \mathrm{l}$ of TEMED were subsequently added and the solution was poured into a petri dish $3.5 \mathrm{~cm}$ diameter) to polymerize and kept away from sunlight for a period of 10-15 minutes.

After the polymerization was complete, the resultant blue cylindrical gels were taken out of the petri dishes, washed with distilled water and then kept moist or dried in a dust-free chamber until the gels were dried completely.

$\lambda_{\text {max }}\left(\right.$ solid, $\left.25{ }^{\circ} \mathrm{C}\right) / \mathrm{nm} 626\left(\varepsilon / \mathrm{dm}^{3} \mathrm{~mol}^{-1} \mathrm{~cm}^{-1} 4729\right), 589$ (6018) and 418 (7087).

IR (neat): $\nu\left(\mathrm{cm}^{-1}\right)=2923,2349,1658,1624,1551,1496$, 1436, 1314, 1250, 1121, 1095, 747, 724.

Synthesis of the control hydrogel (8). $1.91 \mathrm{~g}$ of acrylamide (26.87 mmol), $66 \mathrm{mg}$ of $N, N^{\prime}$-methylenebisacrylamide ( $\left.0.43 \mathrm{mmol}\right)$ were dissolved in $6.6 \mathrm{~mL}$ of water. $100 \mu \mathrm{l}$ of a $10 \%$ solution of SDS
(9.95 $\mathrm{mg}, 0.035 \mathrm{mmol}$ ) and $3.3 \mathrm{~mL}$ of double distilled water were subsequently added and the solution was gently stirred.

$100 \mu \mathrm{l}$ of a $10 \%$ solution of APS and $20 \mu \mathrm{l}$ of TEMED were added and the solution was poured into a petri dish, $3.5 \mathrm{~cm}$ diameter) to polymerize, and kept away from sunlight for a period of 10 minutes.

After the polymerization was over, the resultant transparent cylindrical gels were taken out of the petri dishes, washed with distilled water and then kept moist, or dried in a dust-free chamber.

IR (neat): $\nu\left(\mathrm{cm}^{-1}\right)=1672,1612,1425,1355,1355,1280$, 1134, 988, 960, 841, 817 .

\section{Characterization of the hydrogels by scanning electron microscopy (SEM)}

The morphology of the hydrogels was characterized by fieldemission scanning electron microscopy.

Scanning electron microscope (SEM) images of the hydrogel alone (8) or in the presence of the phenothiazinium compound (7) before and after irradiation with visible light were obtained using a EVO60 scanning electron microscope (Zeiss) fitted with a cryo-preparation system-model: PP3010T, manufacturer: Quorum Technologies.

After plunge-freezing in liquid nitrogen the sample was transferred (under vacuum) to the cryo system preparation chamber.

Most of the water-ice was removed by sublimation by increasing the temperature of the sample from $-140{ }^{\circ} \mathrm{C}$ to $-60{ }^{\circ} \mathrm{C}$ at a pressure of $5 \times 10^{-5}$ mbar for 10 minutes. After this, the temperature of the sample was reduced to $-140{ }^{\circ} \mathrm{C}$ and a pressure of approximately $5 \times 10^{-7} \mathrm{mbar}$.

The sample was then sputter coated with about $2 \mathrm{~nm}$ of platinum and then transferred to the SEM for examination.

The SEM electron beam accelerating voltage used was $15 \mathrm{kV}$ at a probe current of 20-35 pA.

The diameters of the gel pores were determined using the Image J program.

Detection of singlet oxygen generation. Detection of singlet oxygen was determined by photobleaching of the chemical probe, 9,10-anthracenediyl-bis(methylene)dimalonic acid (ABDA) according to a previously published protocol. ${ }^{33}$

ABDA is a water-soluble derivative of anthracene that can be photobleached by singlet oxygen to its corresponding endoperoxide.

$150 \mu \mathrm{mol} \mathrm{L}^{-1}$ of ABDA in PBS solution ( $\left.\mathrm{pH}=7.0\right)$ containing the hydrogels 7 or $8\left(1 \mathrm{mg} \mathrm{cm}{ }^{-3}\right.$ previously cut in 4 squares) was irradiated in a $1 \mathrm{~cm}$ path length spectrofluorimetric cuvette or in a petri dish $(3 \mathrm{~mL})$.

The photobleaching of ABDA was carried out using a CHFXM500 M mercury lamp as light source, in combination with a $550 \mathrm{~nm}$ cut off filter. The ABDA absorbance was recorded in the 300-550 nm wavelength range. The kinetic of ABDA photooxidation was monitored spectrophotometrically following the decrease of the absorbance at $\lambda_{\max }=380 \mathrm{~nm}\left(\lambda_{\max }\right.$ of ABDA $)$ in different irradiation periods in a $1 \mathrm{~cm}$ path length spectrofluorimetric cuvette. 


\section{Antibacterial activity of the hydrogels}

E. coli strain DH5 $\alpha$ contains the plasmid pGLITE, a derivative of pBBR1MCS-2 containing the lux CDABE operon of Photorhabdus luminescens $^{34}$ and bioluminescent $S$. aureus strain RN4220 $0^{35}$ were maintained from frozen stock on nutrient agar (Oxoid Ltd, Basingstoke, UK) and were grown as broth cultures using Reinforced Clostridial Medium (RCM; Oxoid Ltd Basingstoke, $\mathrm{UK})$ with addition of kanamycin $\left(10 \mathrm{mg} \mathrm{l}^{-1}\right)$ or erythromycin $\left(5 \mathrm{mg} \mathrm{l}^{-1}\right)$ for $E$. coli or $S$. aureus respectively, to selectively maintain the lux plasmids.

For experiments on photodynamic killing, microbial cells were obtained by inoculation of test species in $10 \mathrm{~mL}$ volumes of appropriate liquid medium and incubated in a shaking incubator (model S 150, Stuart shakers, UK) at $37{ }^{\circ} \mathrm{C}$ for 4 to 6 hours to obtain mid exponential phase cultures.

A total of $100 \mu \mathrm{L}$ of bacterial suspension was appropriately diluted in $1 \mathrm{~mL}$ PBS (pH $=7.0$ ) to obtain approximately $10^{6}$ colony forming units (cfu) $\mathrm{mL}^{-1}$.

The photoantimicrobial hydrogel (7) was cut into four squares and equilibrated with PBS $(\mathrm{pH}=7.0)$ for 20 minutes. Then the media was discarded, the gel was washed with PBS of the same $\mathrm{pH}$ and placed into the diluted bacterial suspension in borosilicate glass tubes ( 12 by $75 \mathrm{~mm}$; Fisher Scientific, Loughborough, UK) using the same tube for both light irradiation and measurement of bioluminescence light output. The samples were irradiated with a white light at a fluence rate of $14.5 \mathrm{~mW} \mathrm{~cm}{ }^{-2}$ for 20 or 25 minutes (total light dose was either 17.4 or $21.8 \mathrm{~J} \mathrm{~cm}^{-2}$ ).

The illumination was performed using a fiber optic cable $(\Phi=1 \mathrm{~cm})$ and lamp (Fiber Illuminator, OSL1-EC, ThorLabsInc, Ely, Cambridgeshire) with a $150 \mathrm{~W}$ halogen lamp. Luminescence light output was measured by quickly inserting the tube into a FB12 luminometer (Berthold Detection Systems, Germany) to quantify the light output as relative light units (RLU).
A borosilicate tube was similarly treated, but not exposed to light and used as a reference for the dark toxicity under the same experimental conditions.

The hydrogel alone (8) was tested following the same protocol.

Control experiments on E. coli and S. aureus suspensions irradiated and in the dark indicated that light doses alone up to $21.8 \mathrm{~J} \mathrm{~cm}^{-2}$ cause no evident bacterial damage. All experiments were conducted in duplicate.

\section{Results and discussion}

\section{Synthesis and characterization of compounds}

Phenothiazinium tetraiodide (1) has been proven to be a good starting material to obtain the final asymmetric phenothiazinium derivative $\mathbf{6}$ as can be seen in Fig. 2. 1 was successfully synthesized through the oxidation of the commercially available phenothiazine. Phenothiazinium tetraiodide was obtained in almost a quantitative yield using a relatively straightforward process, as the procedure is well established within the literature. ${ }^{31}$ 3-Dimethylaminophenothiazin-5-ium triiodide (2) was subsequently obtained by substitution at $\mathrm{C} 3$ of the phenothiazinium ring in dichloromethane/acetone/methanol mixture under argon with dimethylamine $2 \mathrm{M}$ in methanol in $35 \%$ yield.

Compound 2 was obtained in a reasonable yield (35\%) without complex and expensive separation protocols, involving a water extraction and a subsequent precipitation in diethyl ether.

The target molecule and intermediates were characterized using NMR spectroscopy and Electrospray Mass Spectrometry. The mass spectrum of 2 provides evidence that the molecular peak is at 241.07 as (M) ${ }^{+}$(Fig. S1, ESI $\dagger$ ).

The ${ }^{1} \mathrm{H}$ NMR spectrum of 2 (Fig. S2, ESI $\dagger$ ) shows in the downfield region the two double doublets for the protons at $\delta$ $8.22(\mathrm{H} 9,1 \mathrm{H})$ and $\delta 8.19(\mathrm{H} 6,1 \mathrm{H})$, the multiplet for the protons at $\delta 8.24(2 \mathrm{H})$, and two resolved resonances attributed to $4(2 \mathrm{H})$

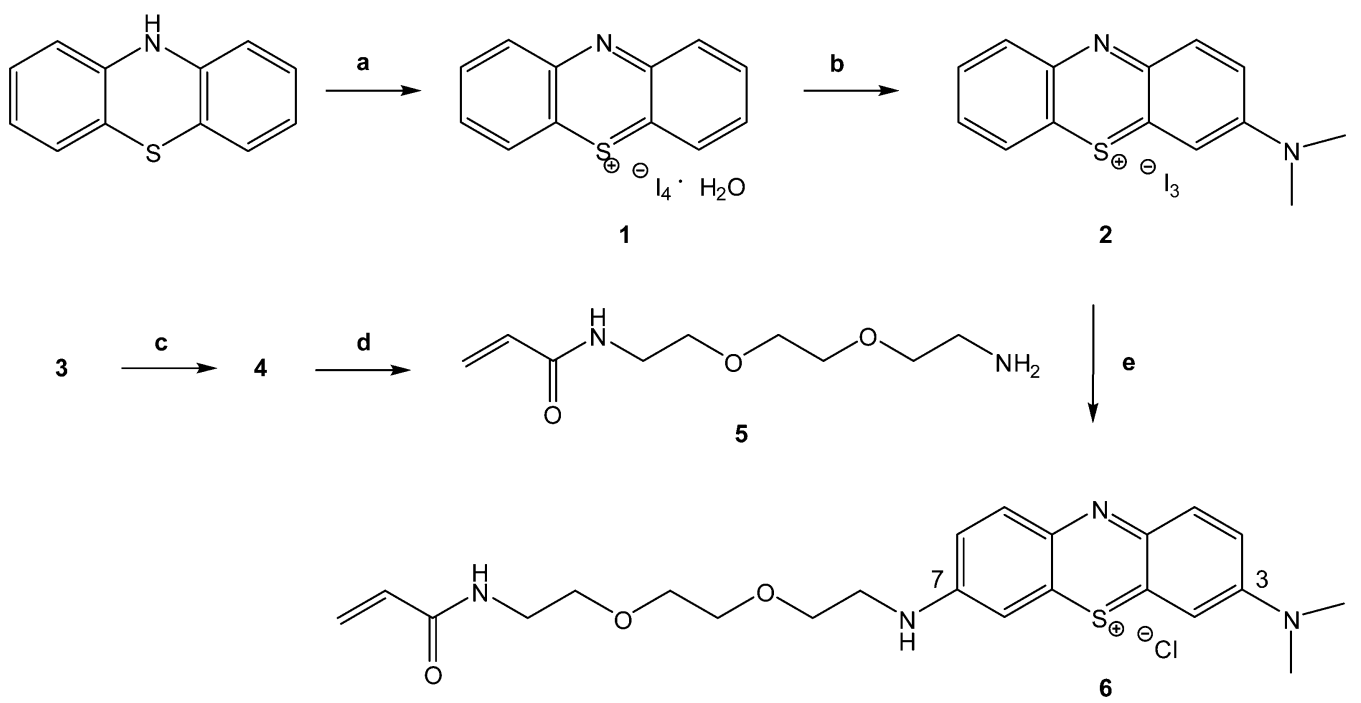

Fig. 2 Synthetic route to 3-(2-(2-(2-acrylamidoethoxy)ethoxy)ethylamino)-7-(dimethylamino)phenothiazin-5-ium chloride (6). Reactions and conditions: (a) $I_{2}$, $\mathrm{CH}_{2} \mathrm{Cl}_{2}, 5 \mathrm{~h}$, rt, 93\% yield. (b) $\mathrm{NH}\left(\mathrm{CH}_{3}\right)_{2}, \mathrm{CH}_{2} \mathrm{Cl}_{2} / \mathrm{MeOH}$ /acetone mixture, $6 \mathrm{~h}, \mathrm{Ar}, \mathrm{rt}, 35 \%$ yield. (c) acryloyl chloride, $\mathrm{DIPEA}, \mathrm{CH}_{2} \mathrm{Cl}_{2}, \mathrm{Ar}, 7 \mathrm{~h}, 0{ }^{\circ} \mathrm{C}-\mathrm{rt}, 70 \%$ yield. (d) $\mathrm{HCl}$ in 1,4-dioxane, rt, $1 \mathrm{~h}, 92 \%$ yield. (e) Alkyl amine, dry $\mathrm{MeOH}, \mathrm{Ar}, 2 \mathrm{~h}, \mathrm{rt}, 76 \%$ yield. 
and $1-2(4 \mathrm{H})$ at $\delta 8.06$ and $\delta 8.09$ respectively. In the upfield region, the spectrum shows only two sharp singlets, at $\delta 3.62$ and $\delta 3.64$ for the $\mathrm{N}\left(\mathrm{CH}_{3}\right)_{2}$ (3H each).

To insert an acryloyl function on the PS, useful for the later covalent immobilization of the photosensitising unit on a polymeric support, 3 was proven to be a suitable starting material. Preparation of the commercially unavailable $\mathrm{N}$-2-[2-(2-aminoethoxy)ethoxy] ethylacrylamide (5) was carried out via standard reactions as previously reported ${ }^{36,37}$ by reaction of 3 with acryloyl chloride following $\mathrm{HCl}-m e d i a t e d$ Boc-deprotection (Fig. 2).

The mass spectrum of 5 provides evidence that the molecular peak is at 203.1387 as $\left(\mathrm{M}+\mathrm{H}^{+}\right)$(Fig. S3, ESI $\dagger$ ).

The ${ }^{1} \mathrm{H}$ NMR spectrum of $\mathbf{5}$ (Fig. S4, ESI $\dagger$ ) shows the characteristic resonances of the acryloyl group at $\delta 6.26$ $\left(\mathrm{CH}_{2}=\mathrm{CHCO}\right), \delta 6.17$ for the $\mathrm{CH}_{2}=\mathrm{CHCO}$ trans and at $\delta 5.75$ for the $\mathrm{CH}_{2} \mathrm{CH}=\mathrm{CO}$ cis. In the upfield region, the spectrum shows the multiplet of the alkylic chain $(\delta=3.80-3.57)$, the triplet at $\delta 3.47$ and the multiplet $\delta 3.19$ of the $\mathrm{CH}_{2} \mathrm{NHCOCH}$ and $\mathrm{CH}_{2} \mathrm{NH}_{2}$ respectively.

Compound 2 was converted to the desired product 6 in $75 \%$ yield using an excess of $\mathbf{5}$ previously synthesized using mild conditions in methanol, at room temperature.

After purification, the counter ion was exchanged for chloride using Amberlite IRA 400, an ion exchange resin.

${ }^{1} \mathrm{H}$ NMR and ${ }^{13} \mathrm{C}$ NMR clearly demonstrated that 6 is an asymmetric structure. It was difficult to obtain good NMR spectra of 6 as iodide, indeed some papers report the synthesis but not the NMR spectra of similar phenothiazinium photosensitisers ${ }^{31,38,39}$ but after the ion exchange with the IRA-400 (Cl) the NMR spectra of phenothiazinium chlorides were easily obtained in deuterated dmso.

Furthermore, iodide ions can react with singlet oxygen being produced from the photosensitiser, which consequently decreases the overall efficiency. The correlation $\mathrm{H}-\mathrm{H}$ COSY spectrum of 6 (Fig. S5, ESI $\dagger$ ) displays, besides the expected cross peaks, also two long range weak correlation peaks between the aromatic protons and the $\mathrm{CH}_{2}$ of the $\mathrm{C} 1$ of the alkylic chain and between the $\mathrm{CH}_{2}$ proton of the $\mathrm{C} 8$ of the alkylic chain and the $\mathrm{NH}$ amide proton that allowed their assignment unambiguously.

Interestingly, all of the protons that belong to the aromatic part, sharp for the precursor 2, now appear quite broad, probably as effect of the aggregation.

Compound 6 gives a single HPLC peak with a retention time distinctly lower than the parent commercially available Azure B ( $\mathrm{rt}=5.92$ and $\mathrm{rt}=6.37$ respectively, Fig. S6 and S7, ESI $\dagger$ ).

It was not possible to compare the retention time of 6 with its precursor 2 due to the low solubility of the latter in the mobile phase.

The final molecule 6 dissolves well in polar solvents such as methanol and ethanol as well as in water and PBS which allows it to be used with a range of different polymer gelification systems where water solubility is often an advantage.

\section{Synthesis and characterization of the hydrogels}

We incorporated our photosensitiser into a polyacrylamide hydrogel because, due to its high porosity, good biocompatibility, its high water content and permeability, ${ }^{40}$ it is widely used in medicine as carrier of immobilized biologically active substances. ${ }^{41,42}$

The hydrogels 7 and $\mathbf{8}$ were obtained through the usual free radical copolymerization of acrylamide (Am) and $N, N^{\prime}$-methylenebisacrylamide in a ratio of 19:1 (w/v\%) using ammonium persulfate (APS) as the redox initiator and $N, N, N^{\prime}, N^{\prime}$-tetramethylethylenediamine (TEMED) as the catalyst.

$11 \mathrm{mg}$ of 6 was dissolved in $3.3 \mathrm{~mL}$ of water and added to the monomers solution at room temperature (total monomer concentration in the final solution: $20 \mathrm{wt} \%$ ). SDS was added to the gel mixture in order to disrupt phenothiazinium dimerization. Dimerization of phenothiazinium produce a blue-shifted absorption band with respect to the absorption band of the corresponding phenothiazine monomer and decreases the singlet oxygen yield. ${ }^{43,44}$

After the addition of the ammonium persulfate (APS) and the tetramethylethylenediamine (TEMED), the homogeneous gel was obtained after 10-15 minutes (Fig. 3, right). Each $\mathrm{cm}^{3}$ of the photoantimicrobial hydrogel (7) contains $1 \mathrm{mg}$ of 6 . The control hydrogel 8 was obtained in a similar way, adding $3.3 \mathrm{~mL}$ of water without the PS (Fig. 3, left).

The gels were then hydrated in deionized water for at least $24 \mathrm{~h}$ with the water being changed three times to remove any unreacted reagents.

This system showed no appreciable leaching of the PS in water. This makes it promising for real-world applications, where leaching of the dye from the material has been observed sometimes, ${ }^{13,21,22}$ limiting the applicability of the material tested.

Morphologies of the gels with the photoantimicrobial hydrogel 7 (Fig. 4a) and of the control hydrogel 8 (Fig. 4b) were analyzed with a scanning electron microscope (SEM).

According to the cross-sectional SEM images, both the copolymer hydrogels $\mathbf{7}$ and $\mathbf{8}$ displayed a continuous and porous structure by virtue of the freeze-drying step, resembling other natural macromolecular hydrogel system structures, with the pores being the result of ice crystal formation. ${ }^{45-47}$

Jiankang et al. ${ }^{48}$ investigated the effect of four different pre-frozen temperatures $\left(-20{ }^{\circ} \mathrm{C}-60{ }^{\circ} \mathrm{C}-90{ }^{\circ} \mathrm{C}-180{ }^{\circ} \mathrm{C}\right)$ on the final the size of micropores of chitosan/gelatin scaffold as well as the wall thickness. He found that, while the pre-freezing temperature has little effect on the wall thickness, it has a great effect on the mean pore size. The mean pore-size became smaller along with

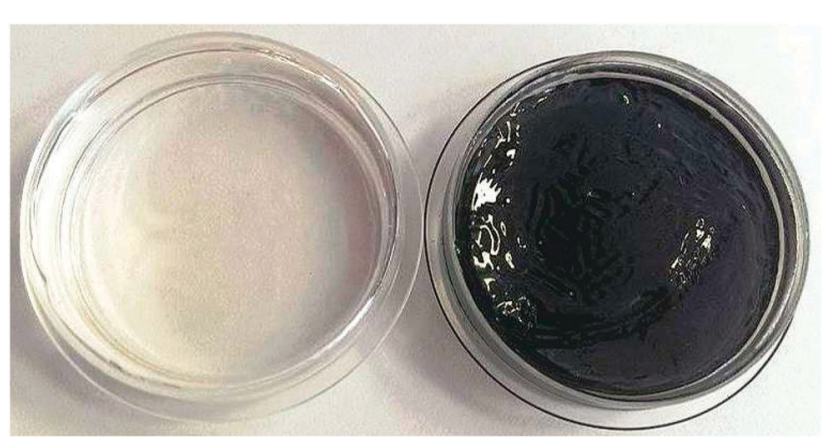

Fig. 3 Photograph of the control hydrogel 8 (left) and of the photoantimicrobial hydrogel 7 (right) with $11 \mathrm{mg}$ of $6\left(10.30 \times 10^{-3} \mathrm{M}\right.$ stock solution in $\mathrm{H}_{2} \mathrm{O}$ ) immobilized in it. 

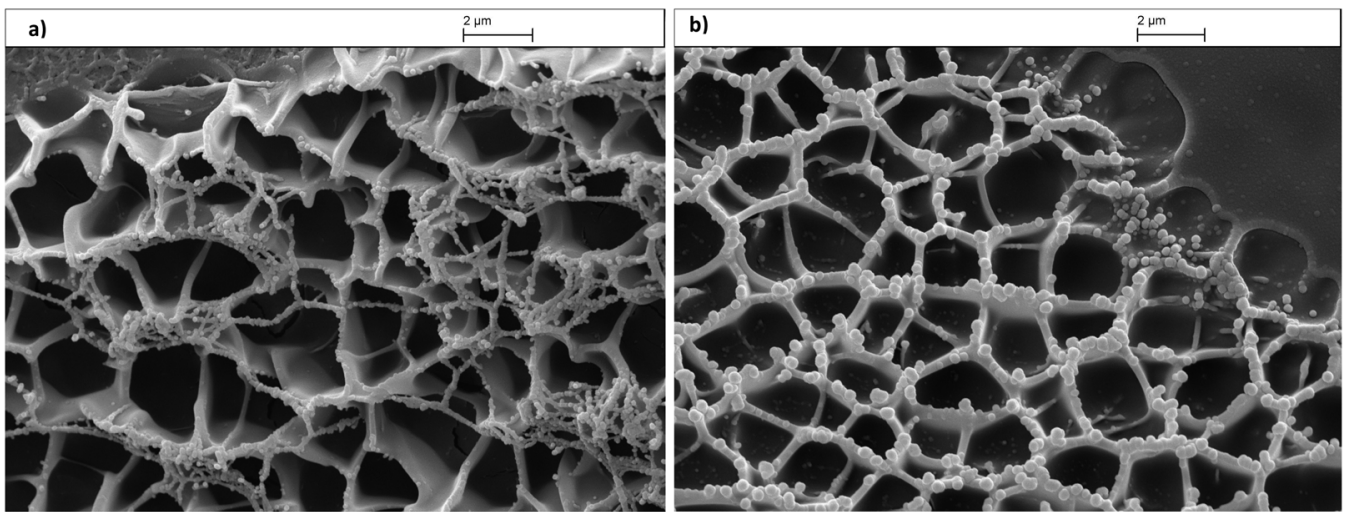

Fig. 4 (a) Scanning electron microscopy (SEM) image of the photoantimicrobial hydrogel 7. (b) Scanning electron microscopy image of the control hydrogel 8

the lower pre-freezing temperature, however it had little effect on the wall thickness. ${ }^{49}$

The spherical pores of freeze-dried hydrogel 7 and 8 have an average diameter of $(166.25 \pm 25.36) \mathrm{nm}$. The image of the gels with the photosensitiser immobilized (Fig. 4a) suggests a similar 'mesh' structure when compared to the control (Fig. 4b). However, there appears to be a finer mesh structure present as well.

SEM analysis revealed the microstructure morphologies of freeze-dried hydrogel 7 after the light treatment (Fig. S8, ESI $\dagger$ ).

The image (Fig. S8, ESI $\dagger$ ) displayed a continuous and porous structure suggesting that our light treatment does not alter the structure of the hydrogel.

In our experiments we used visible light transmitted by a fibre optic cable. UV radiation is most likely to influence the hydrogel properties due to absorption in this spectral region, however, UV is not transmitted by the material of the fibre optic used here. IR could also possibly exert some thermal effects, but once again this is not transmitted efficiently by the fibre optic used, and temperatures at the working surface were closely monitored.

The absorption spectrum of 7 as a solid, shows a band at $420 \mathrm{~nm}$, as well as the characteristic absorption bands at $589.1 \mathrm{~nm}$ and $626.3 \mathrm{~nm}$ (Fig. S9, ESI $\dagger$ ) and the UV-vis spectrum is similar to the one of $\mathbf{6}$ in PBS solution (Fig. S9, ESI $\dagger$ ) which shows the characteristic absorption bands at $420.9 \mathrm{~nm}$ and $583.9 \mathrm{~nm}$ and $626.9 \mathrm{~nm}$. A similar behavior has been already observed for other phenothiazinium dyes, such as methylene blue that is characterized by a different absorbance spectra for its monomeric and dimeric form. Methylene blue monomers have maximum at $664 \mathrm{~nm}$ and dimers at $590 \mathrm{~nm}^{50}$

The dimerization in water, as detected by its absorption spectrum, is both concentration and ionic strength-dependent. ${ }^{44}$

\section{Singlet oxygen generation}

Because the most common mechanism of action of photosensitisers used in PACT (type II mechanism) involves the production of singlet oxygen upon photoexcitation, the generation of reactive oxygen species was confirmed for the photoantimicrobial gel (7) using ABDA as chemical probe.

In the presence of singlet oxygen $\mathrm{ABDA}$ is photobleached through conversion to the corresponding endoperoxide, leading to a reduction in the absorbance bands of the ABDA probe, and thus enabling the reaction to be monitored spectrophotometrically.

The ABDA solution in PBS (pH $=7.0)$ and $1 \mathrm{mg} \mathrm{cm}^{-3}$ of 7 previously cut in 4 squares were placed in a petri dish and irradiated with visible light above $550 \mathrm{~nm}$ and the absorption intensity of ABDA at $380 \mathrm{~nm}$ was monitored every 15 minutes over a period of 90 minutes. A parallel experiment was performed with the control hydrogel 8 , which contained no photosensitiser.

Over the 90 min irradiation period, Fig. S10a (ESI $\dagger$ ) shows that singlet oxygen is generated by the photoantimicrobial hydrogel (7).

No decrease in absorbance occurred using the control hydrogel (8), indicating that singlet oxygen is not produced by the polyacrylamide gel itself (Fig. S10b, ESI $\dagger$ ).

The generation of reactive oxygen species was investigated for the photosensitiser (6) in solution using ABDA as chemical probe following the same experimental protocol.

Although singlet oxygen quantum yields were not determined, incorporation into the gel of the photosensitiser clearly diminishes the singlet oxygen production capacity of the photosensitizer, possibly as a consequence of the physical entrapment (Fig. S10c, $\mathrm{ESI} \dagger)$.

The experiment with the control hydrogel (8) confirms also that that the decrease in absorption of ABDA was a result of the combined effect of the presence of the photosensitising molecule and the illumination and not only of the illumination itself.

\section{Antibacterial activity}

The testing of the hydrogels against bacteria carried out in this work was aimed at understanding the use of the photoantimicrobial hydrogel (7) in real situations and were carried out following a realistic approach. Thus, 7 and $\mathbf{8}$ were mixed with the bacterial suspensions and illuminated almost immediately with white light, to mimic sunlight, for 20 or $25 \mathrm{~min}$.

The results shown in Fig. 5 clearly demonstrate that the $1 \mathrm{mg} \mathrm{cm}{ }^{-3}$ photoantimicrobial hydrogel (7) successfully inactivated both Gram-positive and Gram-negative lux-bioluminescent bacteria through a photosensitisation process.

The use of lux-bioluminescent target cells, coupled with luminometry provides many advantages over conventional methods 
of assessing kill rates which involve viable count methods which are slow to perform and less accurate. Using bioluminescence avoids the need for sub-samples, serial dilutions, plating, incubation and counting of recovered colonies.

Light toxicity against both bacterial strains revealed a higher susceptibility in Gram-positive bacteria, in agreement with data previously published. In fact, exposure of a suspension of Gram-positive bacterium $S$. aureus RN 4220 (MRSA) bacterial cells $\left(2 \times 10^{6} \mathrm{CFU} \mathrm{mL^{-1 }}\right)$ with 7 to visible light for $25 \mathrm{~min}$ at a fluence rate of $14.5 \mathrm{~mW} \mathrm{~cm} \mathrm{~cm}^{-2}$ caused a $3.32 \mathrm{log}$ decrease in the survival of the bacterial cells $\left(2 \times 10^{3} \mathrm{CFU} \mathrm{mL}^{-1}\right)$ with a kill rate of 0.139 and $1 \log$ reduction after 7.2 minutes. 8 exerted no detectable toxic effect on the Gram-positive bacterial cells both in the dark and after exposure to white light for $25 \mathrm{~min}$.

The Gram-negative bacterium $E$. coli exhibited a decrease of $2.30 \mathrm{log}$ after $25 \mathrm{~min}$ irradiation with $7 \mathrm{using}$ the same experimental conditions with a kill rate of 0.085 and $1 \log$ reduction after 11.8 minutes. In the dark, the $1 \mathrm{mg} \mathrm{cm}^{-3}$ photoantimicrobial hydrogel (7) caused a $0.54 \mathrm{log}$ decrease in the survival of the Gram-positive after 25 minutes (kill rate $=0.016$ ) while $1.26 \mathrm{log}$ decrease was observed for the Gram-negative $E$. coli (kill rate of 0.050 and $1 \log$ reduction after 19.8 minutes).

Dark toxicity was therefore found to be low for both Gram types, albeit higher for Gram-negative bacteria, suggesting a lack of essential targeting, which could prove useful in minimizing the possibility of developing resistance.

It was not possible to compare the killing ability of the photoantimicrobial hydrogel 7 and of the same hydrogel with

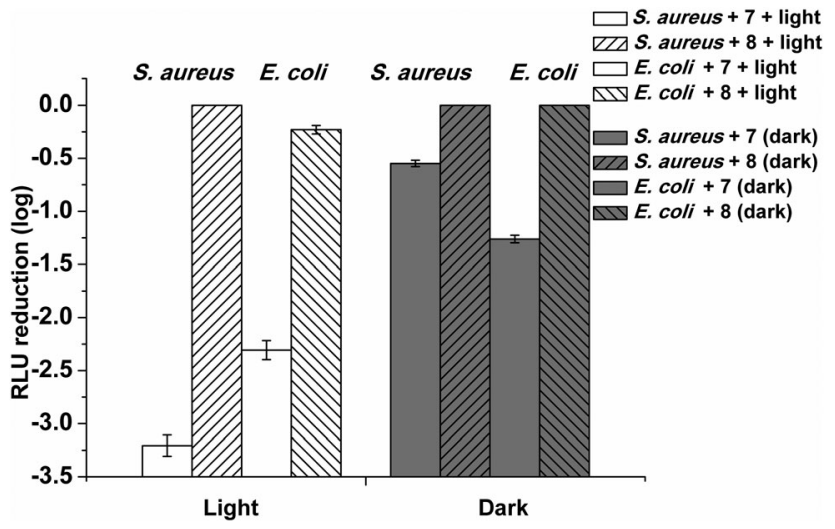

Fig. 5 Biocidal activity of $1 \mathrm{mg} \mathrm{cm}^{-3}$ photoantimicrobial hydrogel (7) previously cut in 4 squares toward $S$. aureus and E. coli in the dark and under light illumination for $25 \mathrm{~min}$ (fluence rate of $14.5 \mathrm{~mW} \mathrm{~cm}^{-2}$ and a total light dose $21.8 \mathrm{~J} \mathrm{~cm}^{-2}$ ). The hydrogel without the PS (8) was used as control in the same experimental conditions. Dark and light experiments were done with the cell suspensions of $2 \times 10^{6} \mathrm{CFU} \mathrm{mL}^{-1}$. The optical fiber was placed $6 \mathrm{~cm}$ from the plates. Values represent the mean of two separate experiments. White bars corresponds to the experiments done adding the photoantimicrobial hydrogel (7) to the $S$. aureus and E. coli suspensions respectively while dark grey bars corresponds to the experiments done in the same way without the illumination. White and dark grey bars with left oblique lines corresponds to the experiments done adding the control hydrogel (8) to the $S$. aureus suspension. White and dark grey bars with right oblique lines corresponds to the experiments done adding the control hydrogel (8) to the $E$. coli suspension. the standard Azure B immobilized on it due to the leaching in the medium of the latter using the same experimental protocol.

In the dark 7 showed a greater killing ability towards the Gram-negative bacterium. This cannot be attributed to the singlet oxygen generation and the mechanism may involve the different interaction with the external bacterial cell wall.

Dark toxicity of methylene blue in solution against Gramnegative species such as $E$. coli has been described previously. ${ }^{51}$ Physical entrapment of methylene blue with gold particles and crystal violet in silicone has been reported to be antimicrobial by light activation, but to also induce killing by a dark-activated mechanism. ${ }^{52}$ However, the ability of chemically immobilized methylene blue to kill bacteria in the dark (where the molecule cannot diffuse into the cell because it is chemically bound) has not been previously reported and the mechanism of killing is unknown.

Interestingly the control (8) was able to cause a reduction only in the Gram-negative $E$. coli $(0.23 \mathrm{log}$ reduction after 25 minutes, kill rate of 0.007) when exposed to the same light irradiation, while in the dark no bacterial killing was observed. Since from the singlet oxygen test the control (8) was found not to be able to produce singlet oxygen when irradiated, the mechanism involved in the killing is unknown.

When the phenothiazinium dye 6 in an unbound state was used under the identical experimental condition a 3 log drop in survival of $E$. coli was obtained after 2 minutes of irradiation and $1.26 \mathrm{log}$ drop in $E$. coli survival cells was observed after 6 minutes in the dark. This higher rate of killing is possibly due to the greater abundance of dye molecules permeating the cell wall and outer membrane. Therefore, we decided to investigate the effects of increasing the contact surface area by using the same total amount of active gel within the assay, but dividing it up into smaller pieces by cutting the gel into 2, 4 or 8 smaller pieces (Fig. S11, ESI $\dagger$ ). This would increase the cell interactive surface area. Therefore, following the same protocol, the $1 \mathrm{mg}$ $\mathrm{cm}^{-3}$ gel 7 was cut in 2, 4 and 8 equal squares and equilibrated for $20 \mathrm{~min}$ in the PBS buffer at $\mathrm{pH}=7.0$. Then the buffer was discarded, the gel was washed with $\mathrm{PBS} \mathrm{pH}=7.0$ and it was added to the $E$. coli suspension in the assay tube.

However, no changes were observed in the kill rates of the target species despite the increases in gel interfacial surface area within the assays. It was possible to observe a kill rate of 0.085 and $1 \log$ reduction after 10.9 minutes under the light and a kill rate of 0.054 and $1 \log$ reduction after 18.5 minutes in the dark. The low dependency of the photo-activity with changes in the surface area of the gel suggested that the gel material was highly porous to the photo-generated active species allowing high diffusion rates and rapid migration of species responsible for killing activity.

On the other hand, as expected, it was possible to observe an increase in the rate of killing by increasing the total amount of the photoantimicrobial hydrogel 7 , going from a $0.27 \mathrm{log}$ drop after 20 min of light exposure from adding 2 squares $\left(0.5 \mathrm{mg} \mathrm{cm}^{-3}\right.$ total amount of PS, killing rate of 0.016$)$ to a $1.65 \mathrm{log}$ drop after 20 minutes by adding 10 squares per assay $\left(2.5 \mathrm{mg} \mathrm{cm}^{-3}\right.$ of total photosensitiser, killing rate of 0.072 and $1 \mathrm{log}$ reduction after 13.8 minutes). 
a) Light

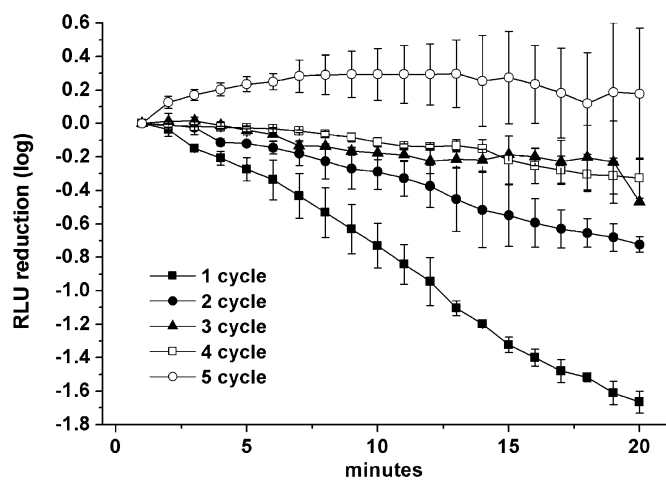

b) Dark

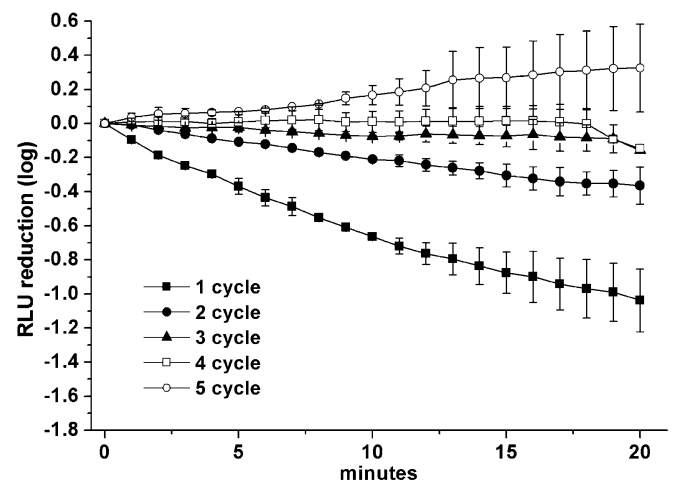

Fig. 6 Kill curves obtained for the $1 \mathrm{mg} \mathrm{cm}^{-3}$ photoantimicrobial hydrogel (7) against E. coli over a total of five cycles both under light illumination (a) for 20 min (fluence rate of $14.5 \mathrm{~mW} \mathrm{~cm}^{-2}$ and a total light dose $17.4 \mathrm{~J} \mathrm{~cm}^{-2}$ ) and in the dark (b). Dark and light experiments were done with the cell suspensions of $4 \times 10^{6} \mathrm{CFU} \mathrm{mL} \mathrm{m}^{-1}$. The optical fiber was placed $6 \mathrm{~cm}$ from the plates. Values represent the mean of two separate experiments.

Again in the dark, the gel 7 exerted a similar behavior, going from a $0.13 \log$ drop with 2 squares (killing rate of 0.009) to a $1.07 \mathrm{log}$ drop after 20 minutes with 10 squares added to the assay (killing rate of 0.057 and $1 \mathrm{log}$ reduction after 17.5 minutes).

The stability of the system in the aqueous medium and the strong photoinactivation of both Gram-positive and Gramnegative bacteria prompted us to investigate the effects of recovering the gel following the photoexcitation of $1 \mathrm{mg} \mathrm{cm}^{-3}$ gel for 20 minutes, and repeating the assays with fresh target cells each time, over a total of five cycles (Fig. 6).

The filled squares correspond to the killing curve obtained for cycle no. 1, the filled circles correspond to the killing curve obtained for cycle no. 2, the filled triangles correspond to the killing curve obtained for cycle no. 3 , the open squares correspond to the killing curve obtained for cycle no. 4, the open circles corresponds to the killing curve obtained for cycle no. 5 .

As before $1 \mathrm{~cm}^{3}$ of the photoantimicrobial hydrogel (7) was cut in 4 squares and equilibrated for $20 \mathrm{~min}$ in the PBS buffer at $\mathrm{pH}=7.0$. Then the media was discarded, the gel was washed with PBS of the same $\mathrm{pH}$ and it was added to a suspension of E. coli cells diluted with $\mathrm{PBS}$ at $\mathrm{pH}=7.0\left(4 \times 10^{6} \mathrm{CFU} \mathrm{mL}^{-1}\right)$.

The bacterial light output was recorded every minute under irradiation with white light for 20 minutes and in the dark. After each cycle the media was discarded, the gel was extensively washed with PBS and reused adding the same squares into a fresh $E$. coli suspension diluted with PBS ( $\mathrm{pH}=7.0)$.

After the first cycle, the photoactivated gel reduced the number of surviving bacterial cells to $8 \times 10^{4} \mathrm{CFU} \mathrm{mL} \mathrm{mL}^{-1}$ (1.62 log decrease after 20 minutes, killing rate of 0.083 and $1 \mathrm{log}$ reduction after 12 minutes).

The gel was then extensively washed with PBS and it was re-used for the disinfection of a newly prepared bacterial suspension containing the same amount of cells $\left(4 \times 10^{6} \mathrm{~mL}^{-1}\right)$.

Following a 20 min irradiation time, an appreciable reduction of $c a$. $0.75 \log$ (to $7 \times 10^{5} \mathrm{CFU} \mathrm{mL}{ }^{-1}$ ) in the viability of the bacterial cells was again achieved (killing rate of 0.040 ).

After the third and fourth cycles, a modest reduction of ca. $0.46 \log$ and $0.41 \log$ in the viability of the bacterial cells was again observed after 20 minutes (killing rate of 0.017 in both cases) while the photo-antimicrobial hydrogel showed no measurable activity during the fifth cycle.

In the dark, the gel showed a similar killing behavior, showing a reduction of $1.17 \log$ after 20 minutes (to $1.5 \times$ $10^{5} \mathrm{CFU} \mathrm{mL}{ }^{-1}$, killing rate of 0.058 and $1 \log$ reduction after 17.2 minutes) after the first cycle, and still showing an appreciable reduction of $0.44 \log$ (to $1.3 \times 10^{6} \mathrm{CFU} \mathrm{mL}^{-1}$, killing rate of 0.02 ) after the second cycle. After the third and fourth cycles, a modest reduction of $c a .0 .16 \mathrm{log}$ and $0.15 \mathrm{log}$ in the viability of the bacterial cells was again observed (killing rate of 0.007 and 0.003 , respectively) whilst the gel showed no activity during the fifth cycle. No phenothiazinium dye was observed to be released from the gel as a consequence of the five irradiation sessions.

\section{Conclusions}

The purpose of this study was to develop an inexpensive, sustainable system for the photosterilisation of water in regions of the world that are facing acute problems of water quality caused by limited conventional water resources. In these areas pure water represents a priority because pathological microorganism espouse a potentially serious health risk for the population.

The use of chemical molecules active against a wide range of bacteria, viruses and fungi whilst at the same time not inducing microbial resistance represents an indubitable advantage.

Methylene blue (MB) and in general phenothiazinium dyes have great potential application due to their broad spectrum of activity which may be due to their attraction by the negatively charged carboxylate groups from teichoic, lipoteichoic and outer membrane long chain carboxylic acids, which are present on the outer surface of bacterial cells. Despite this proven antibacterial potential, the synthesis of novel derivatives of methylene blue often involves long and expensive purifications steps.

We have developed an efficient new strategy that allows the synthesis, purification and immobilization of a new phenothiazinium compound at a much reduced cost. 
An optically transparent polyacrylamide hydrogel was prepared by free radical polymerization of acrylamide (Am) and $N, N^{\prime}$ methylenebisacrylamide using ammonium persulfate (APS) and $N, N, N^{\prime}, N^{\prime}$-tetramethylethylenediamine (TEMED) as the redox initiator and the catalyst respectively.

The photosensitiser bearing a terminal acryloyl group, suitable for the later polymerization and incorporation into a hydrogel, was successfully incorporated into the matrix resulting in an homogeneous and stable conjugate with no observable leaching even after one week in water.

The hydrogel was characterized by IR and scanning electron microscopy and incorporation of the dye confirmed by UV-visible spectroscopy.

SEM pictures confirmed that both the hydrogels with, and without, the PS are porous structures, allowing a large surface area and thus increasing contact between the gel and the bacteria.

The photoactive gel (7) successfully killed $S$. aureus and $E$. coli and the use of bioluminescent target species allowed many variables to be tested such as the effects of dividing the gel to see the effects of increasing the interactive surface area between target cells and immobilized gel and the recovery and further testing of gel through five cycles of fresh challenge.

Further tests using more bacterial strains will be required to understand the applicability of the gel in real conditions, where the water can be infected by many different species of bacteria as well as viruses and fungi.

The synthesized gels meet the intention to use these materials as inexpensive practical systems of water disinfection suitable in remote regions of the world, where healthcare facilities are minimal.

Furthermore, the incorporation of the phenothiazinium chromophore in this hydrogel does not require any specialized condition (e.g. $\mathrm{N}_{2}$, glove box), and in a realistic approach, it can be easily scaled up because it is characterized by an high versatility, as it is possible to shape the gel in any desired form.

\section{Acknowledgements}

The authors would like to thank The Sir Halley Stewart Trust for funding this work. Mass spectrometry data was acquired at the EPSRC UK National Mass Spectrometry Facility at Swansea University. C. S. thanks Dr Saliha Saad and Mr Keith Hewett for their help with the bacterial strain cultures and Mr Tony Sinclair for helpful discussions about SEM interpretation.

\section{References}

1 WHO UNICEF, Progress on Sanitation and Drinking-water: 2010 Update, http://www.unicef.org/eapro/JMP-2010Final. pdf, accessed December 2015.

2 T. H. F. Wong and R. R. Brown, in Water Resources Planning and Management, ed. R. Q. Grafton and K. Hussey, Cambridge University Press, Cambridge, I edn, 2011, vol. 23, pp. 483-504.

3 D. Pittet, B. Allegranzi, J. Storr and L. Donaldson, Int. J. Infect. Dis., 2006, 10, 419-424.

4 B. Allegranzi and D. Pittet, J. Hosp. Infect., 2009, 73, 305-315.
5 J. M. A. Blair, M. A. Webber, A. J. Baylay, D. O. Ogbolu and L. J. V. Piddock, Nat. Rev. Microbiol., 2015, 13, 42-51.

6 M. Wainwright, J. Antimicrob. Chemother., 1998, 42, 13-28.

7 M. R. Hamblin and T. Hasan, Photochem. Photobiol. Sci., 2004, 3, 436-450.

8 P. W. Taylor, P. D. Stapleton and J. P. Luzio, Drug Discovery Today, 2002, 7, 1086-1091.

9 G. Jori, C. Fabris, M. Soncin, S. Ferro, O. Coppellotti, D. Dei, L. Fantetti, G. Chiti and G. Roncucci, Lasers Surg. Med., 2006, 38, 468-481.

10 T. Maisch, Photochem. Photobiol. Sci., 2015, 14, 1518-1526.

11 G. Jori, M. Camerin, M. Soncin, L. Guidolin and O. Coppellotti, in Photodynamic Inactivation of Microbial Pathogens. Medical and Environmental Applications, ed. M. R. Hamblin and G. Jori, The Royal Society of Chemistry, Cambridge, I edn, 2011, vol. 1, pp. 1-18.

12 G. Jori, J. Environ. Pathol., Toxicol. Oncol., 2006, 25, 505-519.

13 C. Spagnul, L. C. Turner and R. W. Boyle, J. Photochem. Photobiol., B, 2015, 150, 11-30.

14 M. Wainwright, Photodiagn. Photodyn. Ther., 2005, 4, 263-272. 15 F. Harris, L. K. Chatfield and D. A. Phoenix, Curr. Drug Targets, 2005, 6, 615-627.

16 M. Wainwright, Int. J. Antimicrob. Agents, 2000, 16, 381-394. 17 S. Perni, P. Prokopovich, I. P. Parkin, M. Wilson and J. Pratten, J. Mater. Chem., 2010, 20, 8668-8673.

18 S. Perni, C. Piccirillo, A. Kafizas, M. Uppal, J. Pratten, M. Wilson and I. P. Parkin, J. Cluster Sci., 2010, 21, 427-438.

19 C. Piccirillo, S. Perni, J. Gil-Thomas, P. Prokopovich, W. Chrzanowski, I. P. Parkin and M. Wilson, J. Mater. Chem., 2009, 19, 6167-6171.

20 S. Ismail, S. Perni, J. Pratten, I. Parkin and M. Wilson, Infect. Control Hosp. Epidemiol., 2011, 32, 1130-1132.

21 S. Perni, C. Piccirillo, J. Pratten, P. Prokopovich, W. Chrzanowski, I. P. Parkin and M. Wilson, Biomaterials, 2009, 30, 89-93.

22 A. J. T. Naik, S. Ismail, C. Kay, M. Wilson and I. P. Parkin, Mater. Chem. Phys., 2011, 129, 446-450.

23 S. Perni, P. Prokopovich, C. Piccirillo, J. Pratten, I. P. Parkin and M. Wilson, J. Mater. Chem., 2009, 19, 2715-2723.

24 R. Cahan, R. Schwartz, Y. Langzam and Y. Nitzan, Photochem. Photobiol., 2011, 87, 1379-1386.

25 M. Wilson, Infect. Control Hosp. Epidemiol., 2003, 24, 782-784.

26 V. Decraene, J. Pratten and M. Wilson, Appl. Environ. Microbiol., 2006, 72, 4436-4439.

27 V. Decraene, J. Pratten and M. Wilson, Curr. Microbiol., 2008, 57, 269-273.

28 N. C. Stellwagen, Electrophoresis, 2009, 30, S188-S195.

29 R. M. Thorn, S. M. Nelson and J. Greenman, Antimicrob. Agents Chemother., 2007, 51, 3217-3224.

30 P. D. Beer, J. Cadman, J. M. Lloris, R. Martınez-Manez, J. Soto, T. Pardo and M. D. Marcos, J. Chem. Soc., Dalton Trans., 2000, 1805-1812.

31 M. Wainwright, K. Meegan, C. Loughran and R. M. Giddens, Dyes Pigm., 2009, 82, 387-391.

32 A. Felgenträger, T. Maisch, D. Dobler and A. Späth, BioMed Res. Int., 2013, 482167.

33 Y. Wang, Y. Liu, G. Li and J. Hao, Langmuir, 2014, 30, 6419-6426. 
34 A. Parveen, G. Smith, V. Salisbury and S. M. Nelson, FEMS Microbiol. Lett., 2001, 199, 115-118.

35 M. Tenhami, K. Hakkila and M. Karp, Antimicrob. Agents Chemother., 2001, 45, 3456-3461.

36 M. Alterman, H. Sjöbom, P. Säfsten, P. O. Markgren, U. H. Danielson, M. Hamalainen, S. Lofas, J. Hulten, B. Classon, B. Samuelsson and A. Hallberg, Eur. J. Pharm. Sci., 2001, 13, 203-212.

37 F. Giuntini, F. Dumoulin, R. Daly, V. Ahsen, E. M. Scanlan, A. S. P. Lavado, J. W. Aylott, G. A. Rosser, A. Beeby and R. W. Boyle, Nanoscale, 2012, 4, 2034-2045.

38 S. A. Gorman, A. L. Bell, J. Griffiths, D. Roberts and S. B. Brown, Dyes Pigm., 2006, 71, 153-160.

39 Y.-T. Lu, C. Arai, J.-F. Ge, W.-S. Ren, M. Kaiser, S. Wittlin, R. Brun, J.-M. Lu and M. Ihara, Dyes Pigm., 2011, 89, 44-48.

40 N. A. Peppas, J. Z. Hilt, A. Khademhosseini and R. Langer, Adv. Mater., 2006, 18, 1345-1360.

41 A. S. Hoffman, Adv. Drug Delivery Rev., 2012, 64, 18-23.

42 J. M. Banks, B. A. C. Harley and B. C. Bailey, ACS Biomater. Sci. Eng., 2015, 1, 718-725.
43 B. Wilson, M.-J. Fernandez, A. Lorente and K. B. Grant, Org. Biomol. Chem., 2008, 6, 4026-4035.

44 J. P. Tardivo, A. Del Giglio, C. Santos de Oliveira, D. S. Gabrielli, H. C. Junqueira, D. B. Tada, D. Severino, R. F. Turchiello and M. S. Baptista, Photodiagn. Photodyn. Ther., 2005, 2, 175-191.

45 H. Tan, C. M. Ramirez, N. Miljkovic, H. Li, J. P. Rubin and K. G. Marra, Biomaterials, 2009, 30, 6844-6853.

46 J. K. Suh and H. W. Matthew, Biomaterials, 2000, 21, 2589-2598. 47 H. Baniasadi, S. A. A. Ramazani and S. Mashayekhan, Int. J. Biol. Macromol., 2015, 74, 360-366.

48 H. Jiankang, L. Dichen, L. Yaxiong, Y. Bo, L. Bingheng and L. Qin, Polymer, 2007, 48, 4578-4588.

49 S. Gorgieva and V. Kokol, J. Biomed. Mater. Res., Part A, 2012, 100, 1655-1667.

50 H. C. Junqueira, D. Severino, L. G. Dias, M. S. Gugliotti and M. S. Baptista, Phys. Chem. Chem. Phys., 2002, 4, 2320-2328.

51 M. N. Usacheva, M. C. Teichert and M. A. Biel, Lasers Surg. Med., 2001, 29, 165-173.

52 S. Noimark, E. Allan and I. P. Parkin, Chem. Sci., 2014, 5, 2216-2223. 